\title{
TEMUAN UANG KEPENG GAMBANGAN DESA GAMBANGAN, KECAMATAN MAESAN KABUPATEN BONDOWOSO, JAWA TIMUR: HASIL KAJIAN AWAL DAN POTENSI PEMANFAATANNYA
}

\author{
Sugeng Riyanto \\ Hery Priswanto \\ (Balai Arkeologi Yogyakarta)
}

\begin{abstract}
This article is a result of an early study of the finding of ancient coins in Gambangan site, Bondowoso Regency, East Java. Based on the findings of the ancient coins and other artifacts, it is assumed that Gambangan site contains a small numbers of archaeological data and its distribution is limited as well. Gambangan site is supposed as a simple settlement site or non permanent settlement site closely related to Majapahit Kingdom. An early study on Gambangan site has described the potentials of the findings in academic field and in the utilization of development such as research materials, education materials and as part of tourist development.
\end{abstract}

Key Words: Mata Uang Kuno, Majapahit, Gambangan

\section{PENDAHULUAN}

Artikel ini didasarkan pada hasil kajian terhadap temuan sejumlah mata uang logam kuno oleh penduduk di Desa Gambangan, Kecamatan Maesan, Kabupaten Bondowoso, Jawa Timur. Kajian ini diawali dari peninjauan terhadap temuan mata uang kuno Gambangan yang dilakukan setelah mendapat laporan dari BP3 Jawa Timur. Dalam laporan tersebut dijelaskan bahwa lokasi penemuan berada pada lahan milik H.M. Trisno Adi Tantiono, seorang ulama, pengusaha, sekaligus ketua PITI (Persatuan Islam Tionghoa Indonesia), yang berdomisili di Desa Gambangan. Lahan tempat temuan adalah lokasi yang sedang disiapkan untuk pendirian pondok pesantren yang dipelopori oleh Pak Haji Trisno Adi Tantiono (Soviani \& Kuswanto, 2009).

Untuk keperluan penyiapan lahan, dilakukan perataan tanah dengan menggunakan buldozer, pada saat itulah ditemukan beberapa keping mata uang logam dan pecahan keramik. Peristiwa ini terjadi pada tanggal 24 Januari 2009 sekitar pukul 09.00 WIB yang disaksikan oleh pengawas proyek. Penemuan ini selanjutnya dilaporkan kepada pemilik lahan dan 
diteruskan ke Dirjen Sejarah dan Purbakala. Titik lokasi penemuan oleh pihak Kepolisian Sektor Maesan diamankan dengan membuat batas garis polisi (police line), sedangkan temuan uang kuno diamankan di kediaman Pak Haji (Soviani \& Kuswanto, 2009).

Penemuan ini memang mengejutkan, terutama dari segi jumlahnya yang mencapai hampir $23 \mathrm{Kg}$. Namun tidak dilaporkan adanya konteks data arkeologi lainnya selain pecahan keramik Cina dari bentuk guci yang diduga berasal dari Dinasti Yuan (abad ke-14 M.). Deskripsi mata uang oleh BP3 Jawa Timur atas empat sampel menunjukkan keseragaman dari aspek, bentuk, yaitu: diameter antara $2,5-2,6 \mathrm{~cm}$; tebal $0,1 \mathrm{~cm}$; dan lubang bagian tengah antara $0,6 \times 0,6 \mathrm{~cm}-0,7 \times 0,7 \mathrm{~cm}$.

Setelah mencermati laporan BP3 Jawa Timur, peneliti Balai Arkeologi Yogyakarta selanjutnya mempelajari konteks kewilayahan secara lebih luas, khususnya potensi sumberdaya arkeologi di kawasan lereng Timur Argopuro. Hasil studi ini menunjukkan bahwa kawasan lereng timur Argopuro secara arkeologis cukup besar potensinya, terutama dari tradisi megalitik. Namun, yang menarik adalah kronologi situs-situs megalitik ini berdasarkan pertanggalan mutlak berkisar antara abad ke-14 hingga ke-16 M. Artinya semasa dengan kerajaan Majapahit (Prasetyo, 1999: 26-27). Jika dibandingkan dengan artefak yang ditemukan di lahan Pak Haji, baik mata uang atau pecahan keramik, maka dapat dikatakan adanya kesamaan masa.

Seperti diketahui bahwa pada saat budaya Hindu-Buddha telah berkembang di Jawa Timur, budaya megalitik tetap hidup subur bahkan hingga pada akhir Majapahit. Fenomena masih berkembangnya budaya megalitik pada masa Majapahit di Bondowoso dan sekitarnya sangat menarik mengingat daerah tersebut merupakan daerah kekuasaan Kerajaan Majapahit yaitu kerajaan yang besar dan perkembangan agama Hindu- Buddha sangatlah kuat (Hidayat, 2007: 27)

Gambaran ini mengisyaratkan bahwa temuan uang kuno dan pecahan keramik memiliki arti penting bagi penelitian arkeologi, khususnya berkaitan dengan konteks data arkeologi masa Majapahit dan tradisi megalitik di kawasan lereng timur Argopuro. Selain itu, dari aspek administratif, Jawa Timur adalah salah satu provinsi yang menjadi wilayah kerja Balai Arkeologi Yogyakarta, di samping DI Yogyakarta dan Jawa Tengah. Berdasarkan hal itu, selanjutnya Balai Arkeologi Yogyakarta membentuk Tim untuk melaksanakan peninjauan atas temuan uang kuno di Desa Gambangan, Kecamatan Maesan, Kabupaten Bondowoso, Jawa Timur.

Untuk itu, tim penelitian Balai Arkeologi Yogyakarta mengadakan penelitian awal untuk mendapatkan gambaran tentang nilai potensi akademik dan gambaran potensi pengembangannya. Potensi akademik didasarkan pada kerangka kronologis dan karakter beserta konteks budaya situs; sedangkan potensi pengembangan meliputi aspek pengembangan penelitian dan pengembangan pemanfaatan. 
Berdasarkan hal itu, maka strategi yang disusun meliputi beberapa hal, sebagai berikut:

1. Pendokumentasian, deskripsi, dan analisis temuan

2. Melaksanakan survei di sekitar lokasi penemuan untuk mendapatkan gambaran konteks data arkeologi maupun konteks lingkungan alami

3. Analisis atas data arkeologi hasil survei

4. Studi pustaka berkenaan dengan hasil penelitian arkeologi di lereng timur Argopuro, khususnya dari masa Majapahit

5. Komparasi hasil analisis dengan hasil studi pustaka

6. Menyusun sintesa berdasarkan hasil komparasi untuk mendapatkan gambaran tentang kerangka kronologis, karakter situs beserta konteks budayanya, serta kerangka pengembangan

\section{HASIL PENINJAUAN}

Penelitian awal difokuskan pada dua hal, yaitu 1) pendokumentasian dan deskripsi atas temuan yang dilaporkan, yaitu mata uang dan pecahan keramik; serta 2) survei di sekitar lokasi penemuan untuk mendapatkan gambaran kondisi situs beserta lingkungannya dan kemungkinan ditemukannya artefak sebagai konteks data arkeologi. Berikut ini adalah uraian lebih lanjut berkenaan dengan pelaksanaan kegiatan peninjuan.

\subsection{Temuan yang Dilaporkan}

Seluruh mata uang yang ditemukan saat ini disimpan di kediaman Pak Haji Trisno Adi Tantiono beserta beberapa pecahan keramik Cina. Saat Tim mengadakan peninjauan dengan didampingi petugas dari Dinas Pariwisata, Budaya, Pemuda dan Olah Raga Kabupaten Bondowoso, kondisi temuan tidak berbeda dengan gambaran dalam laporan BP3, yaitu onggokan mata uang kepeng dengan lubang bujur sangkar di bagian tengah dan sebagian besar telah menyatu antara keping satu dengan lainnya. Demikian pula dengan pecahan keramik Cina yang disimpan dalam kantong yang sama. Selain itu, Pak Haji juga menunjukkan temuan lain berupa kotak logam yang menurutnya berasal dari lokasi di sekitar proyek. Uraian masing-masing artefak yang dilaporkan adalah sebagai berikut.

\subsubsection{Uang Kuno}

Artefak ini berupa bongkahan sekumpulan uang kepeng seberat hampir $23 \mathrm{Kg}$. Meskipun beberapa keping di antaranya lepas, namun sebagian besar telah menyatu dan masih diliputi tanah. Pengukuran yang dilakukan atas beberapa sampel menunjukkan hal sama dengan hasil pengukuran oleh $\mathrm{BP} 3$, yaitu: diameter antara $2,5-2,6 \mathrm{~cm}$; tebal $0,1 \mathrm{~cm}$; dan lubang bagian tengah antara $0,6 \times 0,6 \mathrm{~cm}-0,7 \times 0,7 \mathrm{~cm}$.

Kedua permukaan umumnya aus dan mengalami patinasi berwama hijau sehingga huruf-huruf yang ada sulit dikenali. Namun demikian ada beberapa mata uang lepas yang masih cukup jelas menunjukkan adanya 
aksara yang tertera. Analisis atas huruf-huruf yang tertera sebenamya sangat penting artinya untuk mendapatkan informasi yang ada sehingga penting artinya untuk dilakukan analisis numismatik. Namun, dari hurufhuruf yang dapat terlihat, sangat mungkin mata uang logam ini berasal dari Cina.

\subsubsection{Fragmen Keramik}

Fragmen keramik yang diperlihatkan oleh Pak Haji kepada Tim sebanyak 2 pecahan yang disimpan dalam kantong yang sama dengan uang kuno. Dua pecahan dengan ukuran pada bagian terpanjang $10 \mathrm{~cm}$ dan $7 \mathrm{~cm}$ dan tebal antara $0,4-0,6 \mathrm{~cm}$ ini adalah bagian badan dari wadah yang diduga berbentuk guci. Glasir berwarna kuning kehijauan dengan bercak coklat hingga hitam tampak dominan pada bagian dalam. Dari segi bahan, kedua pecahan ini termasuk kategori batuan (stoneware).

Berdasarkan ciri-ciri ini, diduga pecahan keramik ini adalah berasal dari Cina dari Dinasti Yuan, sekitar abad ke-13 hingga 14 Masehi. Mencermati kedua pecahan tersebut, diyakini bahwa keduanya merupakan fragmen dari benda yang sama. Berdasarkan informasi, pecahan sejenis sebenarnya cukup banyak, namun sebagian besar disimpan oleh beberapa warga secara pribadi. Hal ini mendukung bahwa bentuk asal dari pecahan ini adalah guci. Mengingat kemungkinan besar guci ini satu masa dan berada satu konteks dengan mata uang logam kuno, maka muncul dugaan bahwa guci ini sejatinya merupakan wadah tempat menyimpan mata uang logam tersebut.

\subsubsection{Kotak Logam}

Temuan kotak logam juga ditemukan di lokasi temuan mata logam uang kuno walaupun tidak secara bersamaan. Kotak logam atau tepak (bahasa Jawa) ditemukan oleh salah penduduk di sekitar situs. Temuan ini kemudian dibeli oleh Haji Trisno Adi Tantiono dan disimpan di rumah beliau.

Kotak logam ini berbahan kuningan dan terdiri dari dua bagian yaitu wadah dan tutup yang dihubungkan dengan engsel. Kotak logam ini berukuran panjang $12 \mathrm{~cm}$, lebar $8 \mathrm{~cm}$, dan tinggi $2 \mathrm{~cm}$. Pada bagian tutup dan wadah tidak dijumpai hiasan apapun (polos). Bagian wadah terbagi dalam 3 sekat yaitu dua sekat yang sempit dan lengkapi dengan penutup dan satu sekat dengan ukuran yang lebar dan berada di tengah. Pada saat ditemukan, salah penutup sekat sudah tidak dijumpai. Pada penutup sekat bagian wadah ini dijumpai hiasan geometris berupa jajaran delta (barisan segitiga) di bagian atas dan jajaran persegi di bagian bawah.

Berkaitan dengan fungsinya, kotak logam ini diduga digunakan sebagai kotak penyimpan tembakau dan cengkeh dalam satu wadah sebagai bahan membuat rokok (linthingan). Temuan kotak logam dapat mungkin dapat dikaitkan dengan hasil utama Kabupaten Bondowoso yaitu tembakau yang telah terkenal sejak masa kolonial. (Mashoed, 2004: ix) 

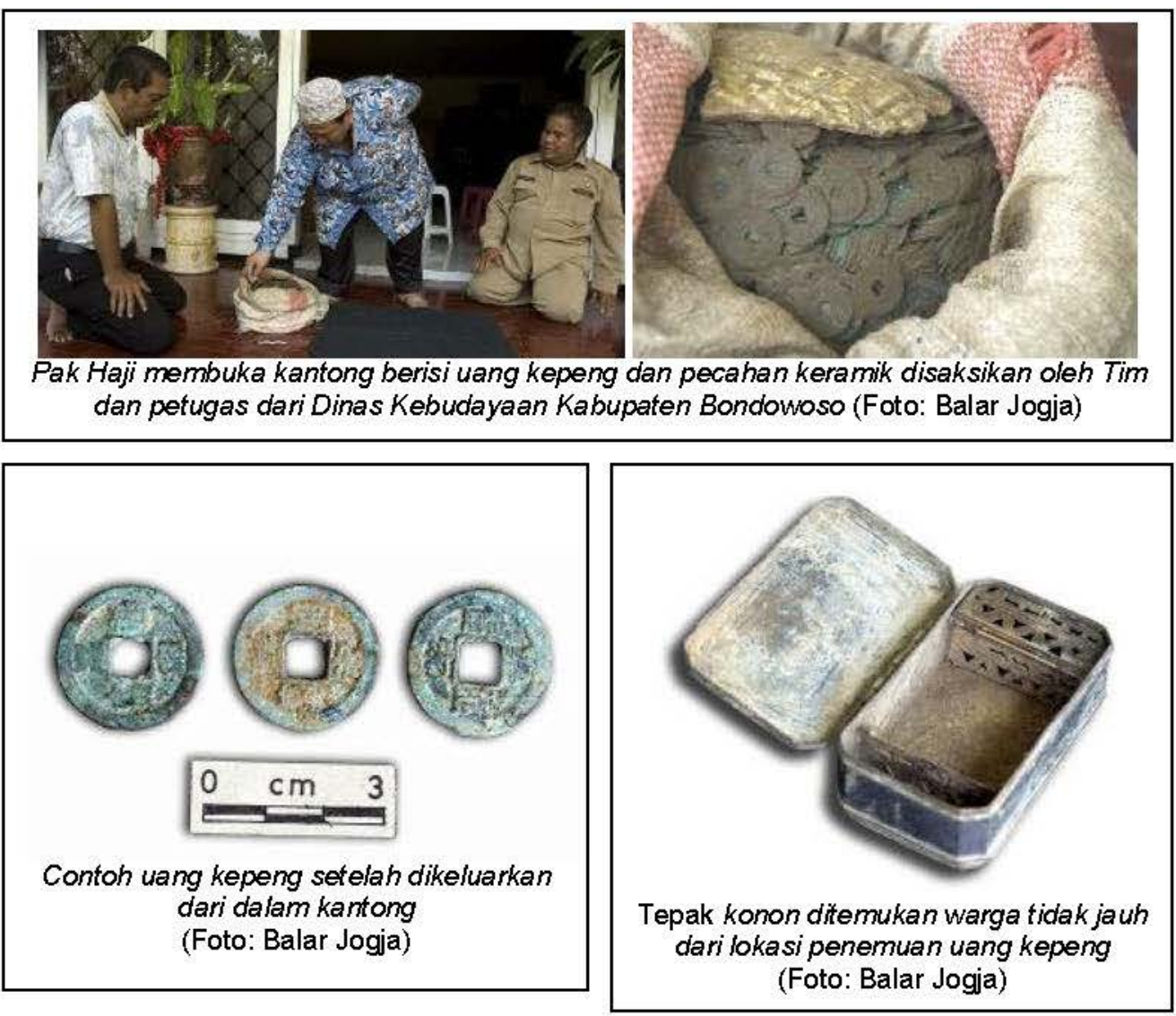

\subsection{Hasil Survei}

\subsubsection{Gambaran Situs dan Lingkungan}

Pemandangan yang pertama kali terlihat di situs adalah hamparan tanah urug berwarna tanah segar seluas sekitar $2 \mathrm{Ha}$. Kondisi lahan sangat kontras dengan lahan di sekitamya yang berwarna kehijauan karena merupakan lahan persawahan yang aktif. Di arah barat hingga barat laut dari lokasi ini tampak Gunung Argopuro (3.088 mdpl) beserta anak-anak gunungnya, yaitu Gunung Krincing, Gunung Tengah, Gunung Gugur, Gunung Saing, dan anak gunung yang terdekat adalah Koong. Pada bagian lereng hingga kaki gunung, lahan pertanian berupa teras-teras artifisial sangat dominan. 
Lokasi temuan yang persis di tepi jalan desa menjadikan area ini sangat mudah dijangkau dan langsung terlihat kekontrasan dengan lahan di sekelilingnya maupun aktifitas proyek yang sedang berlangsung. Pada saat peninjauan, kegiatan proyek memang sedang berlangsung, terutama pembuatan fondasi pagar keliling kompleks pesantren.
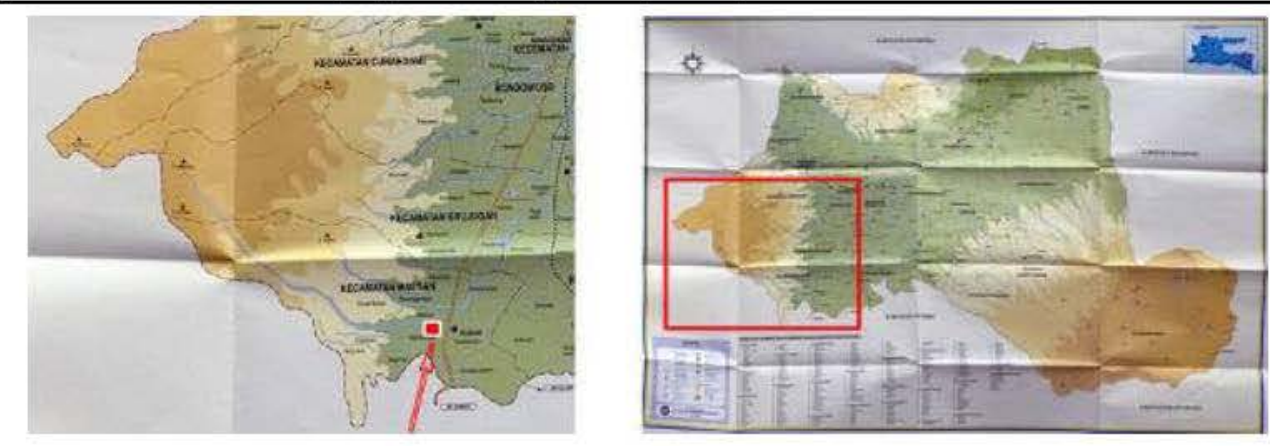

Lokasi stus uang kuno Gambangan

Permukaan lahan yang didominasi oleh tanah urug sebagai hasil perataan tanah menunjukkan bahwa sebelumnya morfologi muka tanah lahan ini adalah teras-teras persawahan. Beberapa bagian lahan masih tergenang air dan rerumputan yang menunjukkan bahwa kegiatan perataan tanah belum selesai sepenuhnya. Menurut informasi, seluruh tanah urug yang digunakan untuk meratakan lahan proyek berasal dari lahan di sekitarnya karena dilakukan dengan cara meratakan lahan dengan buldozer.

Sepintas, permukaan tanah memang tidak menunjukkan keistimewaan, khususnya berkaitan dengan kandungan data arkeologi, termasuk pada titik lokasi tempat ditemukannya uang kuno. Dominasi visual muka tanah adalah pecahan bata dan genteng yang dipastikan merupakan barang baru, serta batu dan kerikil. Dengan kondisi seperti ini, Tim kemudian memutuskan untuk melakukan survei dengan cara menentukan beberap area secara imajiner dan arbriter, yaitu:

a. Area pengamatan dibatasi pada lokasi proyek

b. Area dalam radius sekitar 10 meter dari titik penemuan uang kuno dikategorikan sebagai ring inti

c. Bagian timur dari ring inti dikategorikan sebagai area potensi 1; hal ini karena area ini relatif rata dengan urugan tanah yang cenderung tipis

d. Bagian utara dikategorikan sebagai potensi 2 karena merupakan bekas lahan sawah berteras sehingga urugan tanah cenderung tebal

e. Bagian barat dikategorikan sebagai potensi 3 karena derajat kemiringan lahan yang cukup besar dan bahkan berbatasan dengan cekungan yang cukup dalam

f. Bagian selatan yang berbatasan dengan jalan desa tidak dimasukkan ke dalam area tersendiri dan mengikuti pembagian area di atas.

Berdasarkan pembagian area tersebut maka survei dilakukan dengan cara pengamatan muka tanah dengan teliti jengkal demi jengkal 
untuk mendapatkan kemungkinan adanya artefak. Di sela-sela bongkahan tanah urug, di antara batu, kerikil, pecahan bata dan genteng, Tim menemukan beberapa artefak, di samping indikasi bahwa lahan ini sudah terganggu oleh benda-benda baru.

\subsubsection{Artefak Hasil Survei}

Tingkat ketergangguan situs di area proyek cukup tinggi dengan dijumpainya barang-baru seperti koin Rupiah, botol, plastik, bata dan genteng baru, dan sebagainya. Namun di antaranya Tim menemukan artefak, meskipun dalam jumlah yang kurang signifikan, kecuali temuan uang kuno. Berikut ini adalah uraian mengenai artefak hasil survei.

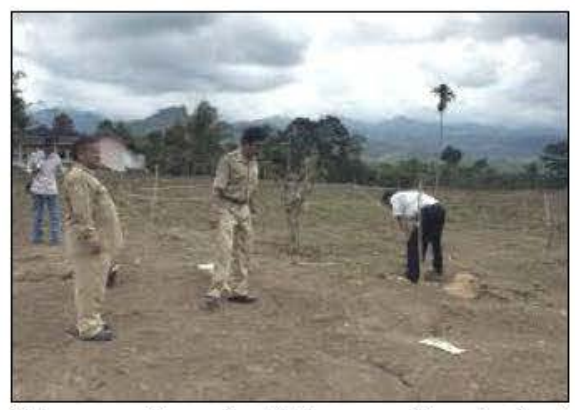

Observasi awal untuk mengatur strategi survei di lokasi proyek pembangunan pesantren (Foto: Balar Jogja)

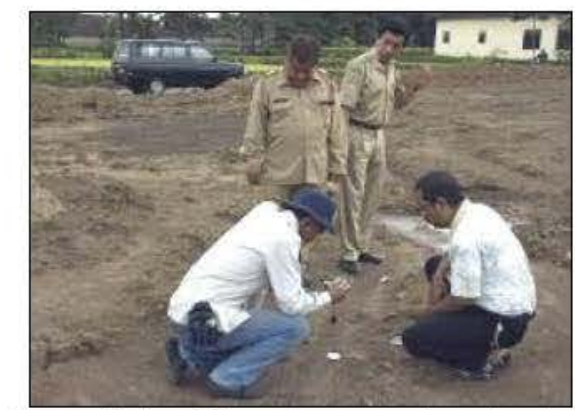

Keramik, tembikar, dan uang kuno berhasil ditemukan, tidak jauh dari area inti (Foto: Balar Jogja)

\subsubsection{Uang Kuno}

Sejumlah mata uang kepeng yang ditemukan dalam survei, yang masih berbentuk utuh ada 3 keping, fragmentaris / patah 1 keping, dan dalam bentuk kumpulan mata uang yang saling melekat berjumlah 9 keping. Mata uang kepeng dengan bahan perunggu pada saat ditemukan sebagian besar sudah mengalami patinasi berwarna hijau dan sudah aus. Hanya beberapa keping saja yang masih dapat dilakukan identifikasi. Mata uang kepeng berbentuk lingkaran pipih di bagian tengahnya terdapat lubang berbentuk bujur sangkar, pada salah sisi di luar lubang tengah terdapat terdapat huruf Cina.Mata uang kepeng ini berdiameter $2,5 \mathrm{~cm}$, tebal $0,1 \mathrm{~cm}$, lubang tengah $0,6 \times 0,6 \mathrm{~cm}$.
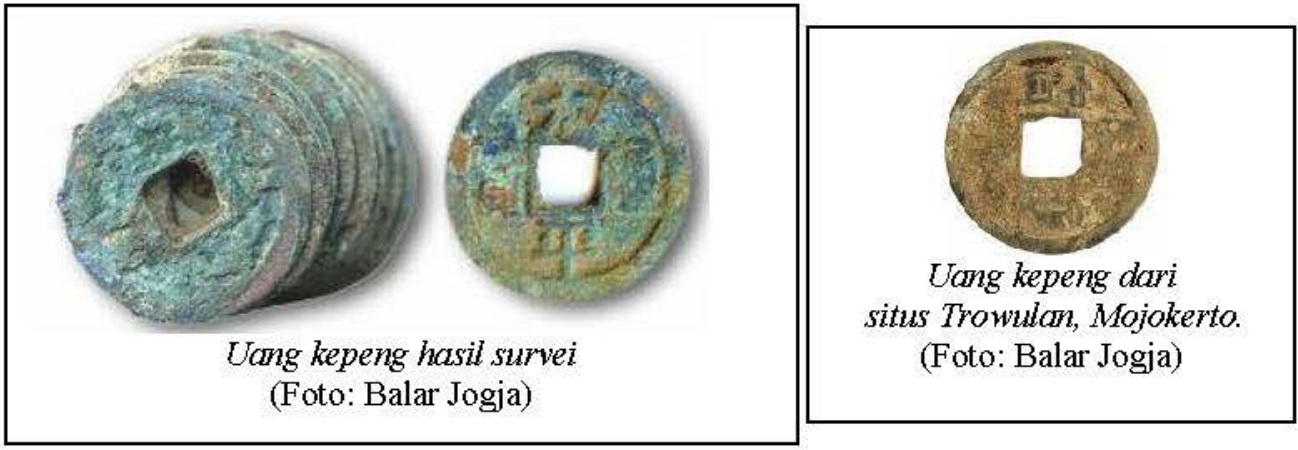

Berkala Arkeologi Tafun XXXX Edisi No. 2 /November 2009 
Dari pengamatan, bentuk huruf Cina pada mata uang kepeng yang ditemukan ini mempunyai kesamaan dengan temuan-temuan mata uang kepeng di Trowulan. Pada masa Majapahit, mata uang kepeng ini jumlahnya sangat banyak dan dipakai sebagai alat transaksi dan satuan nilai dalam perdagangan. Hal ini mengindikasikan adanya kontak antara Bondowoso dengan Majapahit, karena Bondowoso memang merupakan bagian dari wilayah kerajaan Majapahit.

Selain mata uang Cina, pada saat dilakukan survei permukaan di sekitar lokasi temuan mata uang cina juga ditemukan sebuah uang Rupiah senilai Rp 100,- dari tahun 1999 dan sebuah mata uang berhuruf arab pegon pada bagian tengah dan berhuruf Jawa Baru dengan posisi melingkar. Mata uang berhuruf pegon dengan diameter $2,4 \mathrm{~cm}$ ini pada salah satu sisi sudah mengalami aus sehingga tulisan tidak dapat dibaca. Pada sisi lainnya masih relatif jelas walau pada beberapa bagian tertutupi kerak.

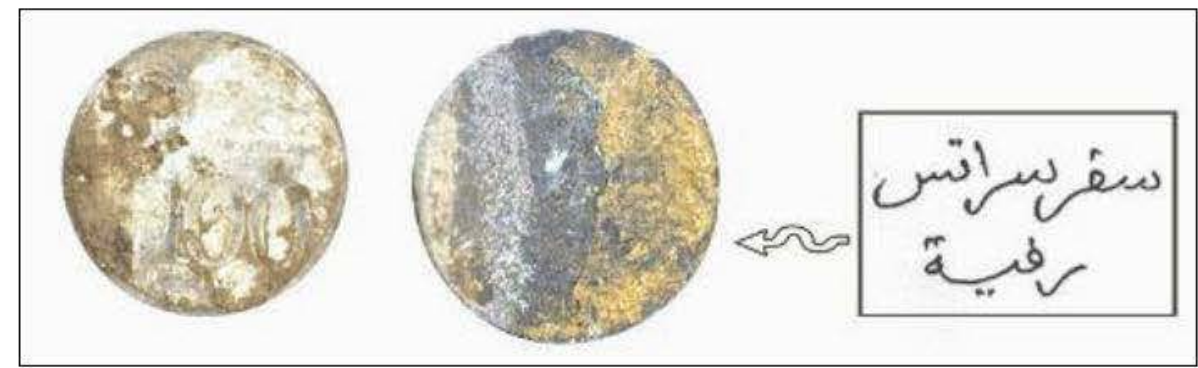

Mata uang logam modern, kiri: Rp 100,- tahun 1999; dan kanan: mata uang logam berhuruf pegon terbaca "seperseratus rupiah" atau 1 sen. Sebuah indikasi bahwa situs telah terganggu (Foto: Balar Jogja)

Hasil pembacaan dan indentifikasi oleh Drs. Masyhudi, peneliti Balai Arkeologi Yogyakarta diperoleh informasi sebagai berikut:

- transliterasi tulisan pada bagian tengah yang masih terbaca adalah berbunyi "seperseratus rupiah" yang berarti senilai 1 sen

- jenis tulisan arab bergaya Naskhi dan berbahasa Pegon (Arab-Melayu).

- terdiri atas 2 baris dan 12 huruf.

\subsubsection{Keramik}

Fragmen keramik yang ditemukan berjumlah 10 keping terdiri atas 6 pecahan berbahan batuan (stoneware) dan 4 pecahan porselen. Seluruh pecahan berbahan stoneware merupakan bagian dari badan wadah dengan dominasi glasir pada bagian luar berwarna kuning kehijauan berbercak coklat hingga hitam. Ketebalan pecahan hingga $0,6 \mathrm{~cm}$ dan berdasarkan analogi diduga merupakan pecahan dari bentuk guci. Jika dibandingkan dengan pecahan yang ditemukan bersama uang kuno, agaknya pecahan ini berasal dari benda yang sama. Oleh karena itu, pertanggalan artefak ini juga diduga berasal dari Dinasti Yuan dari Cina sekitar abad ke-13 atau 14 M. 


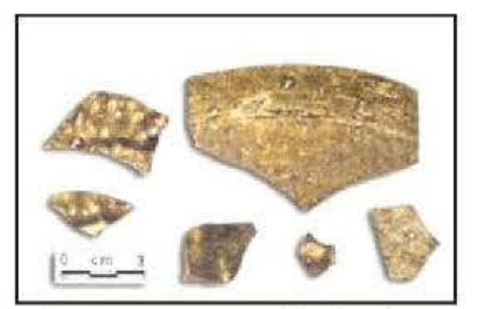

Stoneware yang diperkirakan berbentuk guci dari Cina Dinasti Yuan (abad ke-13/14 M) (Foto: Balar Jogja)

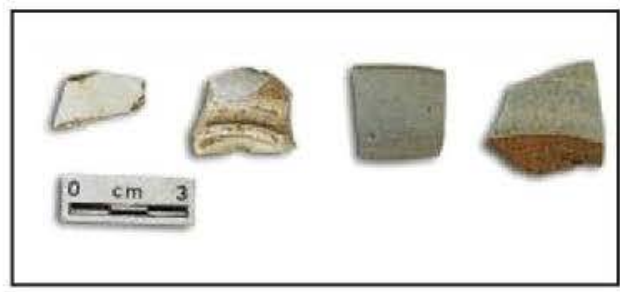

Temuan keramik hasil survei lainnya, pecahan-pecahan dari bentuk wadah yang berlainan, indikasi adanya hunian masa Majapahit (Foto: Balar Jogja)

Sementara itu 4 pecahan porselen terdiri atas 2 keping bagian badan wadah, 1 keping bagian tepian, dan 1 keping bagian dasar wadah. Keempat pecahan ini berasal dari bentuk wadah yang berbeda. Hal ini antara lain dapat dilihat dari warna glasir yang berbeda satu sama lain, dari putih kusam hingga abu-abu. Kecuali pecahan bagian dasar yang diduga merupakan bentuk mangkuk, 3 pecahan lainnya tidak diketahui bentuk asalnya. Secara kronologis, pecahan keramik ini diduga berasal dari Dinasti Ming di Cina, sekitar abad ke-14 atau 15 Masehi.

\subsubsection{Tembikar}

Tembikar yang ditemukan berjumlah 5 keping pecahan dan dari segi adonan (paste) dapat dibedakan menjadi tembikar halus 1 keping dan tembikar kasar 4 keping. Gambaran mengenai masing-masing pecahan tembikar hasil survei adalah sebagai berikut:

- Keping 1: adonan halus dengan bahan berwarna putih hingga merah muda; bagian dasar wadah yang tidak diketahui bentuknya; tebal $0,3-$ $0,4 \mathrm{~cm}$; diameter tidak diketahui; tingkat pembakaran oksidasi merata; dan hiasan tidak ada

- Keping 2: adonan kasar; campuran pasir; bagian tepian; bentuk wadah tidak diketahui; tebal: $1,5-1,9 \mathrm{~cm}$; diameter: $8 \mathrm{~cm}$; tingkat pembakaran menunjukkan oksidasi merata; ada hiasan profil

- Keping 3: adonan kasar; campuran pasir; bagian tepian; bentuk cobek; tebal: $0,4-1 \mathrm{~cm}$; diameter $18 \mathrm{~cm}$; tingkat pembakaran menunjukkan oksidasi merata; ada hiasan slip merah

- Keping 4: adonan kasar; campuran pasir; bagian tepian; bentuk wadah pasu; tebal 0,5 - 0-7 cm; diameter $32 \mathrm{~cm}$; tingkat pembakaran menunjukkan oksidasi merata; ada hiasan slip merah

- Keping 5: adonan kasar; campuran pasir; bagian tepian; bagian pegangan (?); tebal $0,4 \mathrm{~cm}$; diameter tidak diketahui; tingkat pembakaran menunjukkan oksidasi merata; ada hiasan slip merah 


\section{BUTIR-BUTIR PEMIKIRAN}

Hasil peninjauan dan analisis terbatas pada artefak yang ditemukan di Situs Gambangan, Kecamatan Maesan, Bondowoso, Jawa Timur dapat dilihat dari tiga aspek, yaitu: kerangka kronologis, karakter situs dan konteks budaya, serta potensi pengembangannya. Ketiga aspek ini sejalan dengan tujuan kegiatan peninjauan ini yang selengkapnya diuraikan di bawah ini.

\subsection{Kerangka Kronologis}

Secara umum, pertanggalan artefak yang ditemukan, baik uang kuno maupun pecahan keramik berkisar antara abad ke-13 hingga abad ke

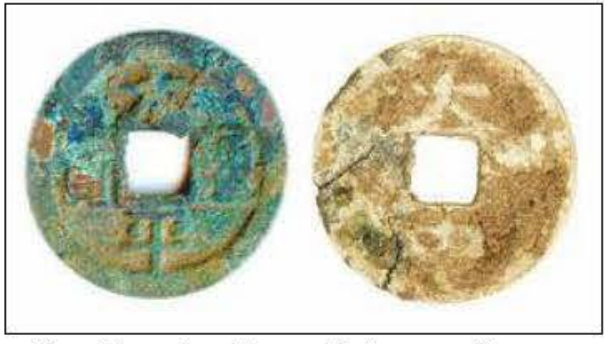

Kemiripan huruf yang tertera pada uang kepeng Gambangan (kir) dan Trowulan (kanan) (Foto: Balar Jogja)

15 Masehi, semasa dengan kerajaan adidaya Majapahit. Khusus untuk koin sebagai temuan utama di situs ini, yang paling dapat dikenali adalah asal pembuatannya, yaitu Cina. Hal ini berdasarkan bentuk huruf yang masih terlihat di keempat bagian antara sisi lubang dengan tepian koin. Analisis lebih dalam mengenai informasi yang dapat diperoleh dari keberadaan hurufhuruf ini memang sangat diperlukan.

Namun demikian, dari beberapa sumber memang disebutkan bahwa setidaknya sejak abad ke-14 di Jawa beredar mata uang logam dari Cina, di samping uang lokal (Djafar, 1991).

Selain itu, berdasarkan perbandingan dengan uang kepeng dari situs Kota Majapahit di Trowulan, temuan mata uang dari Gambangan menunjukkan bentuk yang sama, termasuk kesamaan atau kemiripan huruf-huruf yang tertera. Hal ini mendukung dugaan bahwa koin ini semasa dengan Kerajaan Mahapahit. Perbandingan antara uang kepeng dari situs Gambangan, Bondowoso dan uang kepeng dari situs Kota Majapahit Trowulan, Mojokerto dapat dilihat pada foto berikut ini.

Temuan pecahan guci sebagai temuan serta menjadikan

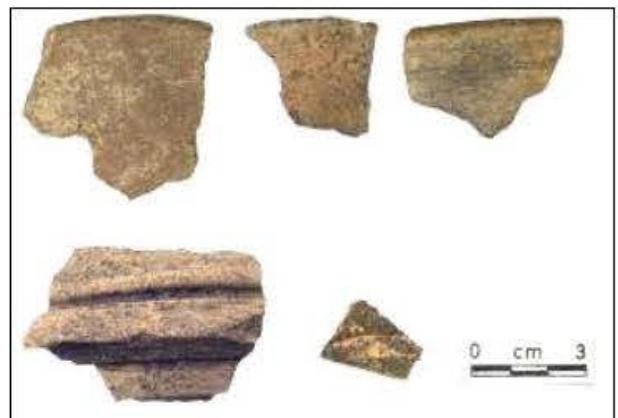

Tembikar hasil survei

(Foto: Balar Jogja) persoalannya semakin menarik. Hasil analisis menunjukkan bahwa pecahan guci ini dan pecahan guci yang disimpan di kediaman Pak Haji merupakan bagian dari benda yang sama. Hal ini memperkuat dugaan bahwa guci inilah yang pada awalnya merupakan wadah bagi mata uang logam kuno yang terangkat oleh buldozer secara tidak sengaja. Pengangkatan yang 
tidak sengaja oleh buldozer ini sekaligus juga memutuskan konteks guci sebagai matriks koin sehingga saat ditemukan dalam keadaan terpisah. Sebagai analogi, mata uang logam yang disimpan dalam sebuah guci juga ditemukan di beberapa situs lain seperti di Desa Kebonagung, Kecamatan Sukodono, Lumajang dan Desa Karangtengah, Kecamatan Bagor, Nganjuk (Soviani \& Kuswanto, 2009).

Mata uang logam sebagai alat tukar dalam perekonomian di Jawa memang sudah dikenal setidaknya pada abad ke-10 $\mathrm{M}$ saat Cina banyak mengimport lada dari Jawa (Amelia, 1986). Tentu saja hal ini juga terjadi saat Majapahit menjadi salah satu negara besar di Asia sekitar akhir abad ke-13 hingga abad ke-15 M. Di sisi lain barang-barang keramik juga menjadi komoditi yang penting, termasuk guci. Namun sebenarnya guci bukanlah komoditi utama, tetapi sebagai wadah bagi komoditi yang sesungguhnya seperti minyak, mentega, arak, dan sebagainya. (Taim, 2002).

Mengingat kemungkinan bahwa mata uang logam dari situs Gambangan ini awalnya tersimpan di dalam guci menimbulkan pemikiran adanya "gejala penimbunan harta" sebagai akibat dari gejolak politik pada saat itu yang kurang menguntungkan atau karena adanya ancaman lain. Informasi yang menyebutkan bahwa mata uang logam dan pecahan guci muncul saat buldozer membongkar dua buah batu besar agaknya memperkuat dugaan bahwa mata uang logam ini merupakan "harta timbunan" yang oleh pemiliknya pada saat itu diberi tanda dengan dua buah batu besar. Namun demikian hal ini masih bersifat sangat hipotetik mengingat konteks dan matriks koin dan guci sudah tidak dapat dikenali lagi. Selama lebih dari dua abad Majapahit berkuasa, memang tidak jarang terjadi gejolak politik yang melibatkan bukan hanya kalangan istana tetapi juga para saudagar.

Nuansa Majapahit
juga tergambarkan dari
pecahan tembikar yang
ditemukan saat pelaksanaan
survei di sekitar lokasi
penemuan uang kuno.
Setidaknya ada dua keping
pecahan yang dapat
dianalogikan dengan artefak
masa Majapahit yang
ditemukan di situs Kota
Majapahit ditus Gambangan (kir) dan kendidarisitus
Mojokerto. Kedua pecahan tembikar tersebut adalah fragmen bagian dasar
dengan bahan adonan halus berwama putih hingga merah muda; dan
pecahan berbahan kasar bagian tepian dengan profil pada bagian luar.


Fragmen tembikar halus mengingatkan pada pecahan yang banyak dijumpai di Trowulan dengan warna antara putih hingga merah muda. Umumnya, tembikar halus dan cenderung tipis ini berbentuk kendi; dan karena cukup dominan maka disebut barang khas Trowulan. Untuk pecahan tembikar kasar yang relatif tebal dengan hiasan profil pada bagian luarnya juga banyak dijumpai di situs Kota Majapahit. Umumnya artefak jenis ini berukuran besar seperti jambangan, vas bunga, dan sebagainya. Dengan demikian, berdasarkan hasil analisis dapat ditegaskan bahwa kronologis situs tempat ditemukannya uang kuno di Desa Gambangan ini adalah semasa dengan kerajaan adidaya Majapahit, sekitar abad ke-13 hingga 15 Masehi.

\subsection{Karakter Situs dan Konteks Budaya}

\subsubsection{Karakter Situs}

Temuan data arkeologi berupa uang kepeng dan pecahan keramik sebagaimana dilaporkan oleh BP3 Jawa Timur serta beberapa artefak yang ditemukan dari kegiatan survei di lahan milik H.M. Trisno Adi Tantiono di Desa Gambangan secara pasti menunjukkan bahwa lahan tersebut adalah sebuah situs arkeologi. Beberapa catatan penting berdasarkan studi atas laporan BP3 Jawa Timur, pengamatan lapangan dan analisis temuan adalah sebagai berikut:

a) sekumpulan mata uang kuno ditemukan pada satu titik, dan mungkin awalnya berada di dalam guci; artinya tidak ada distribusi artefak ini di area situs

b) Uang kuno yang ditemukan dari kegiatan survei juga berada pada area inti dan sangat dekat dengan titik temuan uang kuno; artinya uang kuno hasil survei ini adalah bagian dari kumpulan uang kuno yang ditemukan sebelumnya

c) Artefak yang ditemukan berupa tembikar dan keramik, selain koin, dalam jumlah yang tidak signifikan; artinya kerapatan temuan di situs ini sangat rendah

d) Meskipun demikian, keberadaan koin, tembikar, dan pecahan-pecahan keramik menunjukkan bahwa situs ini merupakan situs hunian dengan tingkat kepadatan rendah dan mungkin bukan hunian permanen

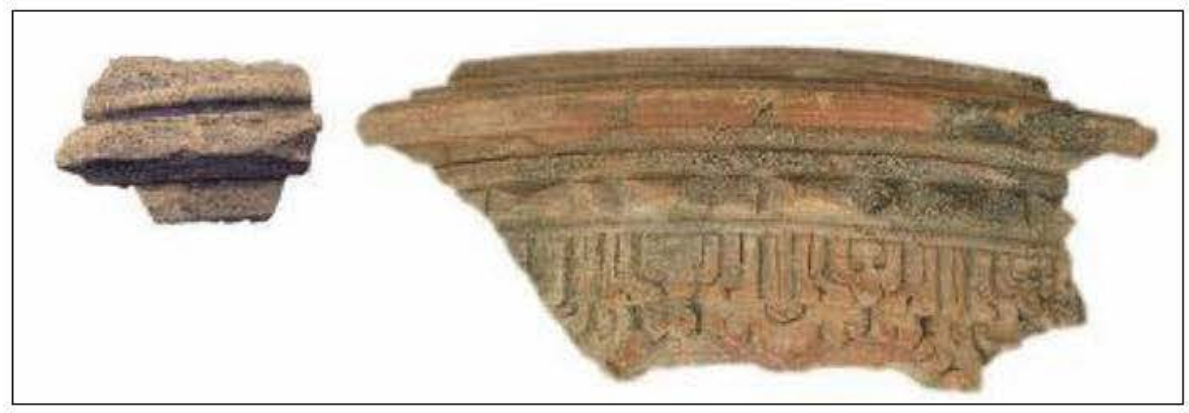

Analogi profil tepian tembikar temuan dari situs Gambangan (kir) dengan temuan dari situs Trowulan, Mojokerto (Foto: Balar Jogja) 
e) Tidak dijumpainya unsur bangunan juga menunjukkan bahwa situs ini bukan situs hunian yang besar dan terstruktur atau memang situs hunian semi permanen dengan komunitas yang relatif kecil

f) Dari segi riwayat situs, terdapat beberapa indikasi gangguan seperti:

- Konteks dengan artefak modem, antara lain berupa koin Rp 100,-koin beraksara pegon senilai seperseratus rupiah (1 sen), botol, plastik, dan sebagainya.

- Modifikasi lahan sebagai area pertanian yang antara lain mengubah morfologi menjadi teras, sebelum kini kembali diratakan

g) Situs uang kuno Gambangan ini pada hakikatnya merupakan bagian dari sebuah sistem budaya yang berkembang pada masa Majapahit; artinya untuk mendapatkan informasi dan penjelasan yang lebih dalam, situs ini tidak sendirian sehingga diperlukan informasi kerangka budaya yang lebih luas sebagai konteksnya

h) Sayangnya, konteks dengan sumberdaya arkeologi lain di sekitar situs maupun lereng timur Argopuro pada umumnya belum jelas; artinya survei arkeologis secara lebih mendalam di sekitar situs maupun di lereng Argopuro menjadi penting artinya guna mengungkap karakter situs beserta kerangka budayanya secara lebih jelas

\subsubsection{Konteks Budaya dan Lingkungan Alami}

\subsubsection{Kawasan Argopuro}

Karakter situs dan konteks budaya tidak terlepas dari faktor lingkungan dimana situs dan budaya berada. Gunung Argopuro - Hyang mempunyai peranan penting dalam membentuk karakter situs dan konteks budaya. Keberadaan Gunung sebagai tempat yang tinggi merupakan tempat arwah para nenek moyang atau Hyang yang kemudian dijadikan nama "Pegunungan Hyang". Situs-situs megalitik yang berada di kawasan Bondowoso apabila ditarik garis imajiner akan mengarah ke pegunungan Hyang. (Mashoed, 2004: 35)

Gunung Argopuro dengan ketinggian 3.088 mdpl termasuk jenis gunung yang mempunyai banyak puncak yaitu kurang lebih 14 buah di jajaran pegunungan Hyang. Kata Argopuro berasal dari kata "argo" dan "puro" yang berarti tempat atau istana yang paling tinggi. (Prihandoko, 2008: 13)

Gunung Argopuro ini memisahkan dua wilayah kabupaten yaitu Kabupaten Probolinggo di sebelah Barat dan Kabupaten Bondowoso di sebelah Timur. Salah satu puncaknya disebut puncak Rengganis dengan ketinggian $2.920 \mathrm{mdpl}$ pernah ditemukan arca Dewi Rengganis. Dewi Rengganis bagi masyarakat yang tinggal di kaki Gunung Argopuro merupakan sebuah legenda yang tersisa mengenai yang bertutur keberadaan seorang putri raja Majapahit yang melarikan diri dan menyepi di puncak ini. Masyarakat yang tinggal di kaki Gunung Argopuro lebih mengenal Gunung Rengganis daripada Gunung Argopuro. Cerita mengenai Dewi Rengganis ini merupakan salah satu legenda yang masih tersisa di masyarakat yang tinggal di kaki Gunung Argopuro. 
Tinggalan arkeologis yang dijumpai di puncak Rengganis yang masih dapat dijumpai berupa tinggalan reruntuhan bangunan candi. Tinggalan arkeologi yang masih mempunyai kaitan dengan legenda Dewi Rengganis yang masih dapat dijumpai di sekitar kawasan Gunung Argopuro yaitu arca Ganesha, Yoni, bangunan yang berfungsi sebagai tempat arca, dan bangunan pintu gerbang atau gapura. Banyaknya tinggalan arkeologis yang dijumpai di Gunung Argopuro ini sehingga Gunung Argopuro ini disebut sebagai gunung seribu candi. (ibid).

Bentang Alam di lereng timur Gunung Argopuro atau tepatnya di kawasan Kabupaten Bondowoso digambarkan bagaikan sebuah mangkuk yang terletak di atas pegunungan dengan dataran rendah di dalamnya, yaitu terletak pada $275 \mathrm{mdpl}$. Dengan wilayah yang subur dan terletak di dataran tinggi bergunung-gunung dan berbukit, kawasan ini menyimpan riwayat sejarah purbakala, hal ini tidak terlepas dari keberadaan Gunung Argopuro.

Hasil pengamatan dan penelitian atas situs-situs arkeologi yang berada di 65 desa dalam 20 kecamatan menunjukkan indikasi bahwa desadesa tempat situs itu secara imajiner menghadap ke arah Gunung Argopuro - Hyang. Beberapa situs arkeologi di wilayah Kabupaten Bondowoso yang berada di sebelah timur Gunung Argopuro adalah:

1. Kecamatan Wringin dengan tinggalan arkeologi berupa sarkofagus berjumlah 53 buah, batu kenong berjumlah 9 buah, kaki dolmen 1 buah

2. Kecamatan Maesan dengan tinggalan arkeologi berupa batu kenong berjumlah 34 buah, dolmen berjumlah 1 buah

3. Kecamatan Pujer dengan tinggalan arkeologi berupa sarkofagus berjumlah 11 buah, batu kenong berjumlah 11 buah, dolmen 61 buah, kaki dolmen 2 buah, batu dakon 1 buah

4. Kecamatan Wonosari dengan tinggalan arkeologi berupa batu kenong 2 buah, dolmen 28 buah, kaki dolmen 2 buah.

Sementara itu, di lereng barat Gunung Argopuro - Hyang dijumpai tinggalan arkeologi berupa tinggalan Candi Kedaton, tepatnya berada di Desa Andung Biru, Kecamatan Tiris, Kabupaten Probolinggo. Candi Kedaton yang terletak di pinggir Sungai Pekalen ini merupakan bangunan candi dengan bahan batu andesit dengan posisi arah hadap candi ke sebelah utara. Candi Kedaton berupa sebuah bangunan batur dengan penampil di sebelah utara. Pipi tangga dihiasi dengan sulur-suluran, hiasan tumpal, dan pada kiri kanan penampil dihiasi miniatur candi. Salah satu pipi tangga bagian depan dipahatkan angka tahun Jawa Kuno 1292 Ç atau $1370 \mathrm{M}$. Dinding batur dikelilingi

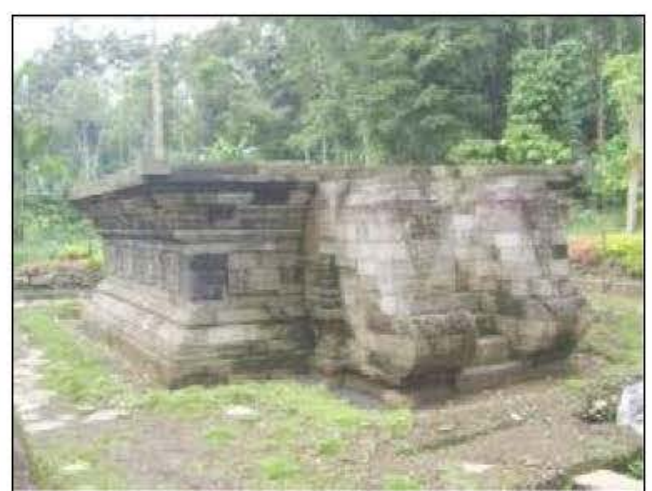

Masyarakat setempat percaya bahwa relief pada Candi Kedaton mengisahkan certa mengenai Dewi Rengganis (Foto: Balar Jogja) 
pahatan relief yang mengisahkan cerita tentang Garudeya, Arjuna Wiwaha, serta Bhomakawya (Bhomantaka) (Kuswanto, 2006: 1).

\subsubsection{Majapahit}

Secara lebih luas, indikasi adanya hubungan dengan kerajaan Majapahit antara lain ditandai oleh artefak uang kepeng dan tembikar. Hal ini bukan hanya menunjukkan adanya benang merah tetapi yang lebih penting adalah adanya konteks budaya peradaban Majapahit yang membingkai perkembangan sejarah dan budaya Bondowoso. Di sisi lain, kedekatan ruang dengan tinggalan-tinggalan tradisi megalitik di sekitar lereng timur Argopuro menjadikan persoalan sejarah budaya Bondowoso semakin menarik.

Tradisi megalitik di Bondowoso dan sekitarnya yang ditandai dengan dominasi batu kenong, dolmen, dan sarkofagus memang menjadi unsur kekayaan budaya yang telah mengemuka sejak lama; dan para peneliti telah banyak melakukan studi yang cukup mendalam. Salah satu informasi dari hasil studi tersebut adalah adanya pembabakan perkembangan tradisi megalitik yang terdiri atas beberapa fase dari abad ke-6 hingga abad ke-19 M (Hidayat, 2007: 27-29). Dari situ tampak bahwa tradisi megalitik bukanlah monopoli masa prasejarah tetapi menembus hingga masa sejarah. Bahkan pada saat peradaban semakin maju yang antara lain ditandai oleh budaya literasi (baca - tulis) yang sudah maju, tradisi ini tetap bertahan sebagai bagian dari kehidupan masyarakat. Dalam kaitannya dengan peradaban kerajaan adidaya Majapahit yang beribu kota di Trowulan, Mojokerto, dapat digambarkan bahwa tradisi megalitik juga berkembang berdampingan dengan pengaruh Majapahit di Bondowoso. Hal ini sangat jelas terlihat paling tidak dari segi ruang dan waktu.

\subsection{Potensi Pengembangan}

\subsubsection{Penelitian}

Meskipun distribusi dan kepadatan data arkeologi di situs uang kuno Gambangan kurang signifikan sebagai sebuah situs permukiman yang besar pada masa Majapahit, namun keberadaannya memiliki kedudukan yang penting karena beberapa hal:

a) Memiliki konteks budaya dengan tradisi megalitik di kawasan Gunung Argopuro, khususnya lereng timur;

b) Secara kronologis situs ini semasa dengan kerajaan Majapahit yang berpusat di Trowulan, Mojokerto, sehingga menjadi bukti bahwa pengaruh Majapahit sampai di Bondowoso;

c) Belum ada penelitian arkeologi yang secara khusus bertujuan untuk menggali potensi sumberdaya arkeologi lereng timur Argopuro secara komprehensif dan terpadu dari Masa Prasejarah, Masa Klasik, Masa Islam, hingga Masa Kolonial, meskipun Kabupaten Bondowoso memiliki potensi tersebut. 


\subsubsection{Pemanfaatan}

\subsubsection{1 bahan penelitian}

a) Artefak berupa uang kuno, pecahan keramik, dan pecahan tembikar patut untuk diamankan sebagai bagian dari data arkeologi yang dapat menjadi bahan penelitian bukan hanya disiplin arkeologi tetapi juga disiplin ilmu lain yang terkait

b) Data tersebut selain menunjukkan adanya benang merah yang menghubungkan dengan budaya Majapahit juga menggambarkan selukbeluk perekonomian dan perdagangan pada masa itu

\subsubsection{2 bahan pendidikan}

a) Hasil penelitian ini yang perlu ditindaklanjuti dengan penelitian komprehensif dan terpadu dari Masa Prasejarah, Masa Klasik, Masa Islam, hingga Masa Kolonial di lereng timur Argopuro. Nantinya hasil penelitian dapat dijadikan sebagai bahan pendidikan baik formal maupun non-formal khususnya di Kabupaten Bondowoso

b) Untuk mendukung pendidikan formal, antara lain dapat ditempuh dengan jalan mengemas hasil penelitian arkeologi di lereng timur Argopuro sebagai bagian dari muatan lokal; sedangkan untuk pendidikan non-formal dapat ditempuh melalui sosialisasi melalui berbagai cara dan media seperti penyuluhan, pameran, pembuatan film pengetahuan, dan sebagainya.

\subsubsection{Sebagai atraksi wisata}

Geliat pengembangan kepariwisataan di Kabupaten Bondowoso yang telah memadukan berbagai unsur, yaitu unsur alam, budaya dan tradisi, bahkan unsur tinggalan arkeologi khususnya tinggalan megalitik sangat membuka peluang untuk menyertakan informasi hasil penelitian nantinya sebagai objek dan daya tarik yang patut diperhitungkan. Seperti diketahui bahwa paradigma dan orientasi kepariwisataan sekarang mulai mengarah kepada wisata khusus yang mengedapankan kekuatan informasi. Hasil penggalian sumberdaya arkeologi yang terpadu di lereng timur Argopuro dirasa sangat cocok dengan orientasi dan paradigma tersebut. Apalagi secara lokasional kawasan lereng timur Argopuro juga menyimpan "eksotika" alami dengan denyut kehidupan pedesaan yang kini menjadi objek yang paling diminati baik oleh wisatawan manca maupun lokal.

Untuk itu, selain penggalian informasi dan pelacakan jejak kejayaan leluhur di Kabupaten Bondowoso, seluruh data yang telah ada maupun yang akan ditemukan nantinya dalam penelitian perlu dilestarikan. Pelestarian ini menjadi aspek yang sangat strategis karena nantinya akan menjadi landasan pemanfaatannya baik untuk kepentingan ilmiah (penelitian), sarana pendidikan, dan kepariwisataan. 


\section{PENUTUP}

\subsection{Simpulan}

Beberapa simpulan yang dirasa penting untuk dikemukakan adalah sebagai berikut:

- Karakter situs temuan uang kuno Gambangan memiliki distribusi dan kepadatan data arkeologi yang relatif tipis; sehingga kemungkinan merupakan situs hunian yang sederhana dan tidak terstruktur atau bahkan situs hunian tidak permanen

- Situs Gambangan ini memiliki benang merah dengan kerajaan Majapahit, antara lain berdasarkan kronologi artefak uang kepeng, keramik, maupun tembikar

- Penemuan kumpulan uang kuno pada satu titik dan bahkan mungkin awalnya berada di dalam sebuah guci yang ditandai dengan dua buah batu besar membawa pemikiran adanya gejala "penimbunan harta" yang diperkirakan dilakukan pada abad ke-13 hingga $15 \mathrm{M}$

- Morfologi situs telah mengalami gangguan baik karena modifikasi lahan sebagai area pertanian dengan teknik teras maupun dengan adanya kegiatan lain. Hal ini diindikasikan dengan keberadaan berbagai artefak modern

\subsection{Rekomendasi}

Beberapa rekomendasi dapat disampaikan dalam kesempatan ini:

- Memberikan penghargaan secara khusus kepada Bapak H.M. Trisno Adi Tantiono sebagai pemilik lahan yang telah menyerahkan temuan arkeologis penting dari lahan miliknya

- Pendataan dan pengamanan secara khusus atas seluruh temuan uang kuno dari situs ini sejalan dengan pengamanan dan pelestarian data arkeologi yang sudah ada, khususnya benda-benda tradisi megalitik

- Memasang papan informasi secara permanen di area situs yang antara lain berisi tentang jenis benda yang ditemukan, penemu, serta waktu dan kronologi. Papan informasi ini sangat penting artinya untuk menandai situs ini, bahkan jikaperlu dilengkapi dengan foto dan replika "bongkahan" uang kuno. Papan informasi ini dirasa sangat strategis dan signifikan mengingat pembangunan pondok pesantren harus terus berjalan demi kepentingan publik dan akan menghapus jejak lokasi penemuan. Dengan demikian nantinya bangunan pesantren akan dapat berdampingan dengan papan informasi tersebut, dan peristiwa penemuan uang kepeng akan menjadi bagian dari riwayat pendirian pesantren

- Menyusun program penelitian arkeologi secara komprehensif dan terpadu dari masa prasejarah hingga masa islam / kolonial untuk menggali potensi sumberdaya arkeologi di kawasan lereng timur Argopuro beserta kemasan-kemasan informasi hasil penelitian dalam berbagai media sehingga dapat dimanfaatkan untuk berbagai kepentingan. 


\section{KEPUSTAKAAN}

Amelia, 1986. Mata Mata uang logam Cina dari Sitis Trowulan. Skripsi. Fakultas Sastra Universitas Indonesia

Djafar, Hasan. 1991. "Data tentang Perekonomian Majapahit dari Sumbersumber Asing" dalam Rapat Analisis Sumber Tertulis Masa Klasik. Trowulan.

Hidayat, Muhammad, 2007. "Menengok Kembali Budaya dan Masyarakat Megalitik Bondowoso", Berkala Arkeologi. Tahun XXVII Edisi No. 1/Mei. HIm. $19-30$.

Kuswanto, 2006. Laporan Penelitian Arkeologis dalam Pemugaran Candi Kedaton, Dukuh Lawang Kedaton, Desa Andungbiru, Kec. Tiris, Kab. Probolinggo. Trowulan: BP3 Jawa Timur.

Mashoed. 2004. Sejarah dan Budaya Bondowoso. Papyrus: Surabaya.

Prasetyo, Bagyo. 1999. "Megalitik di Situbondo dan Pengaruh Hindu di Jawa Timur", Berkala Arkeologi. Tahun XIX Edisi No. 2/ November. Yogyakarta: Balai Arkeologi Yogyakarta. HIm.: 22 -29.

Prihandoko, 2008."Menguak Kehidupan Masa Lampau di Balik Indahnya Argopuro", Jejak. Vol. 1/1 Maret 2008. Jakarta: Mapala UI. HIm. 12 15

Soviani, Aris \& Kuswanto. 2009. Laporan Peninjauan Temuan Uang Kepeng di Desa Gambangan, Kecamatan Maesan, Kabupaten Bondowoso. Trowulan: BP3 Jawa Timur.

Taim, Eka Putriana. 2002. "Keramik Asing di Situs Bangunan Air Karanganyar Palembang" dalam Kumpulan Makalah PIA VIII. Jakarta: IAAI 